\title{
HUBUNGAN PENGETAHUAN DENGAN SIKAP TERHADAP ABORSI KRIMINALIS PADA REMAJA PUTRI DI SMA TAMAN MULIA TAHUN 2017
}

\section{Alexander ${ }^{1}$, Elise Putri ${ }^{2}$}

\author{
Akademi Kebidanan Panca Bhakti Pontianak
}

Email korespondensi: akbidpbpontianak@gmail.com

\begin{abstract}
Abstrak
Aborsi kriminalis adalah aborsi yang terjadi akibat tindakan yang tidak legal atau tidak berdasarkan indikasi medis. Angka kejadian aborsi di Indonesia di perkirakan mencapai 2,3 juta pertahun, sekitar 750.000 dilakukan oleh remaja. Hasil studi pendahuluan di SMA Taman Mulia adalah terdapat 4 siswi yang dikeluarkan dari sekolah karena hamil diluar nikah dan hasil wawancara dari 8 responden bahwa sebagian besar yang mengetahui tentang aborsi kriminalis yaitu 3 (37,5\%). Penelitian ini bertujuan untuk mengetahui Hubungan Pengetahuan Dengan Sikap Terhadap Aborsi Kriminalis Pada Remaja Putri Tentang Aborsi Kriminalis Di SMA Taman Mulia Tahun 2017. Penelitian ini menggunakan desain penelitian analitik korelasi dengan pendekatan cross sectional. Populasi sebanyak 79 siswi dan jumlah sampel 44 siswi dengan teknik sampling aksidental. Instrument penelitian ini menggunakan kuesioner. Hasil penelitian pengetahuan remaja putri tentang aborsi kriminalis yaitu sebagian besar berpengetahuan cukup yaitu 29 (65,90\%), sebagian kecil berpengetahuan baik yaitu 13 (29,54\%), sedangkan berpengetahuan kurang yaitu $2(4,54 \%)$ dan sikap remaja putri sebagian besar bersikap tidak mendukung yaitu 28 $(63,63 \%)$ dan sebagian kecil bersikap mendukung 16 (36,36\%). Dari uji statistik X2 hitung $=0,072<\mathrm{X} 2$ tabel 5,991 dan hasil dari $\mathrm{p}$ value $0,891>0,05$, maka Ha ditolak dan Ho diterima. Pengetahuan remaja putri tentang aborsi kriminalis yaitu sebagian besar berpengetahuan cukup yaitu 29 (65,90\%), dan bersikap tidak mendukung yaitu $28(63,63 \%)$ serta hasil uji statistik X2 hitung $=0,072<\mathrm{X} 2$ tabel 5,991 dan hasil dari p value 0,891 >0,05 dengan demikian dapat disimpulkan bahwa tidak ada hubungan pengetahuan dengan sikap terhadap aborsi kriminalis pada remaja putri di SMA Taman Mulia Tahun 2017. Oleh karena itu disarankan untuk meningkatkan pengetahuan siswi dengan memberikan banyak informasi mengenai aborsi kriminalis, serta bekerja sama dengan puskesmas atau institusi kesehatan untuk pemberian materi tentang aborsi kriminalis kemudian untuk membentuk program genre (PIK-KRR).
\end{abstract}

Kata Kunci: Pengetahuan, Sikap, Aborsi Kriminalis

\section{Pendahuluan}

Kesehatan Reproduksi Remaja (KRR) secara umum didefinisikan sebagai kondisi sehat dari sistem, fungsi, dan proses alat reproduksi yang dimiliki oleh remaja, yaitu laki-laki dan wanita berusia 10-24 tahun (BKKBN-UNICEF, 2004). Remaja masih merupakan salah satu sasaran pembangunan kesehatan di Indonesia pada tahun 2015 karena masa remaja merupakan periode pematangan organ reproduksi manusia yang ditandai dengan munculnya hormon seksual dan permulaan reproduksi seseorang diikuti dengan perubahan fisik secara cepat serta tidak seimbang dengan

perubahan kejiwaan yaitu mental dan emosionalnya khususnya dalam mengontrol hasrat seksualnya (Kumalasari, 2012).

Masalah kesehatan reproduksi pada remaja di Indonesia antara lain rendahnya pengetahuan remaja tentang kesehatan reproduksi dimana hanya $17,1 \%$ wanita dan $10,4 \%$ laki-laki yang mengetahui secara benar tentang masa subur dan resiko kehamilan, sebesar 55,2\% remaja wanita dan 52\% remaja laki-laki usia 15-24 tahun yang mengetahui kemungkinan hamil dalam sekali berhubungan seks dan akses pada informasi yang benar

\footnotetext{
${ }^{1}$ Dosen Akademi Kebidanan Panca Bhakti Pontianak

${ }^{2}$ Dosen Akademi Kebidanan Panca Bhakti Pontianak
} 
tentang kesehatan reproduksi sangat terbatas, baik dari orang tua, sekolah, maupun media masa. Budaya "tabu" dalam pembahasan seksualitas menjadi suatu kendala kuat dalam hal ini.

Masih belum memadainya jumlah Pusat Informasi dan Konseling Kesehatan Reproduksi Remaja (PIK-KRR) dan minat remaja mengetahui KRR secara benar menyebabkan akses informasi ini rendah. Teknologi saat ini memudahkan untuk mengakses situs pornografi sehingga cendrung mendorong terjadinya seks pra nikah (Kumalasari, 2012). Berdasarkan hasil Survey Demografi dan kesehatan Indonesia (SDKI) tahun 2007-2012 diketahui jumlah remaja putri yang melakukan seks pra nikah pada usia 15-19 tahun yaitu sebesar 1,3\% pada tahun 2007 dan mengalami penurunan pada tahun 2012 menjadi 0,7 \% dari total remaja yang ada (SDKI, 2012).

Status kesehatan reproduksi seorang remaja akan berpengaruh pada masa depan remaja. Rendahnya pemahaman remaja akan kesehatan reproduksi menjadi penyebab perilaku seks beresiko seperti pergaulan bebas yang berdampak pada upaya tindakan aborsi. Menurut Survei Kesehatan Reproduksi Remaja Indonesia (SKRRI) tahun 2007 dilaporkan sebanyak 84 orang (1\%) dari responden pernah mengalami Kehamilan tidak diinginkan, dan $60 \%$ diantaranya mengalami atau melakukan aborsi (SKRRI, 2007). Sedangkan SDKI tahun 2012 tentang kesehatan reproduksi remaja tahun 2012 diketahui bahwa 3 dari 10 remaja wanita dan $18 \%$ pria mengaku mengetahui seseorang yang mereka kenal secara pribadi yang mengalami kehamilan yang tidak diinginkan (SDKI, 2012).

Angka kejadian aborsi di Indonesia di perkirakan mencapai 2,3 juta pertahun, sekitar 750.000 dilakukan oleh remaja. Program kesehatan reproduksi yang dikembangkan oleh pemerintah tidak hanya untuk yang sudah menikah dan tidak merujuk pada kebutuhan yang terkait dengan informasi seksualitas, edukasi dan penyediaan pelayanan. Bermula dari hubungan seks pranikah atau seks bebas adalah terjadi kehamilan yang tidak diinginkan (KTD). Ada 2 hal yang bisa dilakukan oleh remaja, yaitu mempertahankan kehamilan dan mengakhiri kehamilan (aborsi). Semua tindakan tersebut membawa dampak baik fisik, psikis, sosial, dan ekonomi (Marmi, 2015).

Abortus provocatus criminalis adalah aborsi yang terjadi oleh Karena tindakantindakan yang tidak legal atau tidak berdasarkan indikasi medis, sebagai contoh aborsi yang dilakukan dalam rangka melenyapkan janin sebagai akibat hubungan seksual diluar perkawinan (Marmi, 2015).

Umumnya aborsi yang tidak aman terjadi karena tidak tersedianya pelayanan kesehatan yang memadai. Apalagi bila aborsi dikategorikan tanpa indikasi medis, seperti korban perkosaan, hamil diluar nikah, kegagalan alat kontrasepsi dan lain-lain. Ketakutan dari calon ibu dan pandangan negatif dari keluarga atau masyarakat akhirnya menuntut calon ibu untuk melakukan pengguguran kandungan secara diam-diam tanpa memperhatikan resikonya (Ambarwati, 2009). 
Pergaulan yang sangat bebas bagi remaja yang masih duduk dibangku sekolah, misalnya SMA, mengakibatkan kecelakaan dan membuahkan kehamilan. Karena merasa malu, dengan teman-temannya, takut kalau kesempatan belajarnya terhenti dan barang kali masa depannya pun menjadi buruk. Ditambahkan tekanan masyarakat yang menyisihkan sehingga akhirnya ia melakukan aborsi supaya tetap eksistensi di masyarakat dan dapat melanjutkan sekolah (Marmi, 2015).

Pemahaman remaja akan kesehatan reproduksi menjadi bekal remaja dalam berperilaku sehat, bertanggung jawab, dan pendidikan kesehatan reproduksi bagi remaja untuk dapat memberikan pengenalan dan pencegahan bagi remaja dalam mensosialisasikan pengetahuan dan sikap remaja tentang reproduksi yang sehat, pada kenyataan tidak semua remaja memperoleh informasi yang cukup dan benar tentang kesehatan reproduksi tersebut. Keterbatasan pengetahuan dan pemahaman ini dapat membawa remaja kearah perilaku beresiko seperti pergaulan bebas dan upaya aborsi kriminalis (Imron, 2012).

Berdasarkan hasil penelitian yang dilakukan oleh Fera Yulistina tahun 2014 tentang Pengaruh Pendidikan Kesehatan Tentang aborsi Terhadap Pengetahuan dan Sikap Remaja Putri Tentang Aborsi di SMK Widya Praja Ungaran bahwa banyaknya kasus aborsi khususnya dikalangan remaja terjadi akibat kesenjangan informasi Terhadap kesehatan reproduksi. Sampel penelitian meliputi 30 siswi kelas XI dan di dapatkan hasil penelitian pada kelompok intervensi terhadap pengetahuan remaja putri 7 reponden $(46,7 \%)$ kategori pengetahuan cukup dan sesudah diberikan pendidikan kesehatan tentang aborsi sebanyak 9 responden $(60,0 \%)$ kategori pengetahuan baik dengan $\mathrm{p}$ value $0,000<\alpha$ $(0,05)$, sikap remaja putri sebanyak 9 responden $(60,0 \%)$ bersikap negatif dan sesudah diberikan pendidikan kesehatan tentang aborsi sebanyak 13 (86,7\%) bersikap positif dengan $\mathrm{p}$ value $0,000<\alpha(0,05)$. Ada pengaruh pendidikan kesehatan terhadap pengetahuan remaja putri tentang aborsi dengan $\mathrm{p}$ value $0,001<\alpha(0,05)$. Ada pengaruh pendidikan kesehatan terhadap sikap remaja putri tentang aborsi dengan $\mathrm{p}$ value $0,008<\alpha$ $(0,05)$.

\section{Metode}

Penelitian ini menggunakan jenis penelitian deskriptif korelasional dengan pendekatan cross sectional. Penelitian dilaksanakan pada bulan Februari hingga Juni 2017 di SMA Taman Mulia Kabupaten Kubu Raya. Populasi penelitian yaitu seluruh siswa kelas X dan XII sebanyak 79 orang. Peneliti menggunakan teknik sampling aksidental sehingga diperoleh sebanyak 44 orang menjadi sampel. Pengumpulan data menggunakan kuesioner kemudian diolah dan dianalisis menggunakan analisis univariate serta analisis bivariate menggunakan uji chi square. 
Hasil dan Pembahasan

Tabel 1. Karakteristik Responden

\begin{tabular}{lcc}
\hline \multicolumn{1}{c}{ Karakteristik } & $\mathrm{n}$ & $\%$ \\
\hline Pengetahuan & 2 & \\
$\quad$ Kurang & 29 & 4,54 \\
Cukup & 13 & 65,90 \\
Baik & & 29,54 \\
Sikap & 28 & 63,63 \\
$\quad$ Tidak Mendukung & 16 & 36,36 \\
$\quad$ Mendukung &
\end{tabular}

Berdasarkan hasil tabel 1 bahwa pengetahuan remaja putri tentang aborsi kriminalis didapatkan hasil sebagian besar dari responden memiliki pengetahuan yang cukup yaitu 29 orang $(65,90 \%)$, sedangkan sangat sedikit dari responden memiliki pengetahuan yang kurang yaitu 2 orang $(4,45 \%)$. Berdasarkan hasil tabel 1 diperolehkan data dari 44 responden menunjukan sebagian besar dari responden memiliki sikap yang tidak mendukung terhadap aborsi kriminalis yaitu 28 orang $(63,63 \%)$.

Tabel 2. Analisis Hubungan Pengetahuan dengan Sikap Istri dalam Pemilihan Kontrasepsi Metode Ovulasi Billings

\begin{tabular}{|c|c|c|c|c|c|c|c|c|}
\hline \multirow{3}{*}{ Variabel } & \multicolumn{4}{|c|}{ Sikap } & \multirow{2}{*}{\multicolumn{2}{|c|}{ Total }} & \multirow{3}{*}{$\mathrm{X}^{2}$} & \multirow{3}{*}{ P Value } \\
\hline & \multicolumn{2}{|c|}{ Memilih } & \multicolumn{2}{|c|}{ Tidak Memilih } & & & & \\
\hline & $\mathrm{n}$ & $\%$ & $\mathrm{n}$ & $\%$ & $\mathrm{n}$ & $\%$ & & \\
\hline Baik & 1 & 2,27 & 1 & 2,27 & 2 & 100 & & \\
\hline Pengetahuan Cukup & 19 & 22,72 & 10 & 43,18 & 29 & 100 & 0,891 & 0,072 \\
\hline Kurang & 8 & 11,36 & 5 & 18,18 & 13 & 100 & & \\
\hline
\end{tabular}

Berdasarkan tabel 2 menunjukan bahwa sebagian dari responden $(43,18 \%)$ yaitu 19 responden yang pengetahuan cukup dengan sikap mendukung dan sangat sedikit dari responden $(2,27 \%)$ yaitu 1 responden yang pengetahuan kurang dengan sikap yang mendukung dan tidak mendukung. Dari uji statistic Chi Square didapatkan nilai X2 hitung adalah $0,072<\mathrm{X} 2$ tabel 5,991 dan didapatkan hasil dari P Value 0,891 >0,05, maka Ha ditolak dan Ho diterima sehingga dapat disimpulkan bahwa tidak ada hubungan yang signifikan antara pengetahuan dengan sikap aborsi kriminalis.
Dari tabel 2 didapatkan hasil sebagian pengetahuan remaja putri tentang aborsi kriminalis didapatkan hasil sebagian besar dari responden memiliki pengetahuan yang cukup yaitu 29 orang $(65,90 \%)$, sedangkan sebagian kecil dari responden memiliki pengetahuan yang baik yaitu 13 orang $(29,54 \%)$, dan sangat sedikit dari responden memiliki pengetahuan yang kurang yaitu 2 orang $(4,45 \%)$. Dari pendapat peneliti hal ini dapat diartikan bahwa pengetahuan seseorang akan baik, apabila mendapatkan informasi yang baik juga sehingga informasi tersebut dapat memberikan pengaruh pada tingkat pengetahuan. 
Dari hasil penelitian banyak responden yang tidak bisa menjawab pertanyaan tentang resiko aborsi kriminalis yang dilakukan oleh dukun beranak karena kurang mendapatkan informasi mengenai dampak atau resiko aborsi kriminalis yang dilakukan oleh dukun. Sebagian besar responden masih memiliki pengetahuan yang cukup yakni $65,90 \%$ dan responden yang memiliki pengetahuan yang kurang 4,45\% ini disebabkan oleh kurangnya remaja mendapatkan informasi-informasi penting khususnya tentang resiko aborsi kriminalis, karena di sekolah tidak ada kegiatan penyuluhan tentang aborsi kriminalis.

Banyak faktor yang mempengaruhi pengetahuan siswa terhadap bahaya seks pranikah seperti informasi yang didapat dari intansi pendidikan terkait, media masa, teman sebaya dan lain sebagainya, semakin sering mereka mendapatkan informasi mengenai seks pranikah atau kesehatan reproduksi maka akan meningkatkan pengetahuan mereka mengenai bahaya dari seks (Handayani \& Setyawan. 2015).

Menurut Fitrani (2011) pengetahuan merupakan hasil dari tahu, dan ini terjadi setelah orang melakukan penginderaan terhadap suatu objek tertentu. Penginderaan terjadi melalui panca indera manusia, yakni indera pengelihatan, pendengaran, penciuman, rasa dan raba. Sebagian besar pengetahuan diperoleh melalui mata dan telinga. Pengetahuan akan berpengaruh terhadap seluruh aspek kehidupan manusia baik pikiran, perasaan maupun sikapnya. Semakin tinggi tingkat pengetahuan semakin tinggi pula kemampuan yang dimiliki remaja.
Hasil penelitian ini berbeda dengan hasil penelitian yang dilakukan oleh Fera Yulistina tahun 2014 tentang Pengaruh Pendidikan Kesehatan Tentang aborsi Terhadap Pengetahuan dan Sikap Remaja Putri Tentang Aborsi di SMK Widya Praja Ungaran bahwa banyaknya kasus aborsi khususnya dikalangan remaja terjadi akibat kesenjangan informasi terhadap kesehatan reproduksi. Sampel penelitian meliputi 30 siswi kelas XI dan di dapatkan hasil penelitian pada kelompok intervensi terhadap pengetahuan remaja putri 7 reponden $(46,7 \%)$ kategori pengetahuan cukup dan sesudah diberikan pendidikan kesehatan tentang aborsi sebanyak 9 responden $(60,0 \%)$ kategori pengetahuan baik dengan $p$ value 0,000 $<\alpha(0,05)$, sikap remaja putri sebanyak 9 responden $(60,0 \%)$ bersikap negatif dan sesudah diberikan pendidikan kesehatan tentang aborsi sebanyak 13 (86,7\%) bersikap positif dengan $p$ value $0,000<\alpha(0,05)$.

Berdasarkan hasil analisis data tersebut dapat disimpulkan bahwa ada pengaruh pendidikan kesehatan terhadap pengetahuan remaja putri tentang aborsi dengan $\mathrm{p}$ value $0,001<\alpha(0,05)$. Ada pengaruh pendidikan kesehatan terhadap sikap remaja putri tentang aborsi dengan $p$ value $0,008<\alpha(0,05)$. Pihak sekolah berkerjasama dengan pihak puskesmas untuk pemberian materi tentang kesehatan reproduksi yang salah satunya adalah aborsi kriminalis kemudian untuk membentuk program genre (PIK-KRR).

Dari hasil penelitian tentang sikap didapatkan bahwa remaja putri tentang aborsi kriminalis sebagian dari responden yaitu 28 responden $(63,63 \%)$ menyatakan tidak 
mendukung dan sebagian kecil responden yaitu 16 responden (36,36\%) menyatakan mendukung. Menurut Notoatmodjo (2010) sikap adalah juga respon tertutup seseorang terhadap stimulus atau objek tertentu, yang sudah melibatkan faktor pendapat dan emosi yang bersangkutan (senang- tidak senang, setuju-tidak setuju, baik-tidak baik, dan sebagainya) dari tabel dapat dilihat bahwa sikap responden tentang bahaya aborsi terbanyak adalah cukup.

Menurut Campbell (1950) dalam Notoatmodjo (2010) mendefinisikan sangat sederhana, yakni; "Anindividual's attitude is syndrome of respons consistency with regard to object." Jadi jelas, disini dikatankan bahwa sikap itu suatu sindroma atau kumpulan gejala dalam merespon stimulus atau objek, sehingga sikap itu melibatkan pikiran perasaan, perhatian, dan gejala kejiwaan yang lain.

Penelitian ini berbeda dengan hasil penelitian Mimatum Nasihah (2015) yang berjudul "Gambaran Pengetahuan Dan Sikap Remaja Putri Terhadap Aborsi di Madrasah Aliyah Negeri Lamongan" Dari pengumpulan data sikap responden diperoleh 23 responden (57.5\%) bersikap negatif, 17 responden $(42.5 \%)$ bersikap positif.

Demikian juga dengan penelitian Mohammad Reza Husain (2012) yang berjudul "Tingkat Pengetahuan dan Sikap Remaja Putri Terhadap Bahaya Aborsi Di SMAN 1 Manado" memperlihatkan sikap responden terhadap bahaya aborsi. Diketahui sebanyak 54 responden (56.8\%) memiliki sikap yang baik, 36 responden $(37,9 \%)$ memiliki sikap yang sedang dan 5 responden (5.3\%) memiliki sikap yang kurang terhadap aborsi.

Sikap yang baik akan dapat menentukan tindakan yang baik dalam menghadapi masalah kehidupan. Bahaya aborsi terhadap kesehatan secara fisik antara lain kematian, perdarahan, infeksi, kemandulan. Selain itu resiko terhadap kesehatan mental antara lain mengalami perasaan-perasaan takut, panik, tertekan atau stress, trauma mengingat proses aborsi kriminalis.

Mengingat bahayanya aborsi kriminalis siswi dapat mencegah terjadinya hal yang tidak di inginkan dengan mendapatkan informasi yang lebih mengenai kesehatan reproduksi, membentengi diri dengan agama, menjauhkan hal-hal yang berbau pornografi dan sering melakukan aktivitas positif.

Dari hasil penelitian berdasarkan tabel 4.3 menunjukan bahwa sebagai dari responden $(43,18 \%)$ yaitu 19 responden yang pengetahuan cukup dengan sikap mendukung dan sangat sedikit dari responden $(2,27 \%)$ yaitu 1 responden yang pengetahuan kurang dengan sikap yang mendukung dan tidak mendukung.

Berdasarkan hasil dari uji statistic Chi Square didapatkan nilai X2 hitung $0,26<\mathrm{X} 2$ tabel 5,991 dan diapatkan hasil dari P Value maka Ha ditolak dan Ho diterima, sehingga dapat disimpulkan bahwa tidak ada hubungan yang signifikan antara antara pengetahuan dengan sikap terhadap aborsi kriminalis pada remaja putri di SMA Taman Mulia tahun 2017. Dari data memperlihatkan pengetahuan remaja dapat dikatakan cukup mengenai aborsi kriminalis karena terbukti bahwa dari 44 responden terdapat 29 responden yang 
pengetahuan cukup dan 19 responden yang tidak mendukung terhadap aborsi kriminalis, maka dari hal ini menunjukan bahwa pengetahuan tidak mempengaruhi sepenuhnya terhadap sikap seseorang.

Keterbatasan pengetahuan dan pemahaman remaja akan kesehatan reproduksi dapat membawa remaja kearah prilaku beresiko seperti pergaulan bebas dan upaya aborsi kriminalais (Imron, 2012). Pergaulan yang sangat bebas bagi remaja yang duduk di bangku sekolah, misalnya SMA, mengakibatkan kecelakaan dan membuahkan kehamilan. Karena merasa malu, dengan teman-temannya, takut kalau kesempatan belajarnya terhenti dan barang kali masa depannya pun menjadi buruk. Ditambahkan tekanan masyarakat yang menyisihkan sehingga akhirnya ia melakukan aborsi supaya tetap eksistensi di masyarakat dan dapat melanjutkan sekolah (Marmi,2015).

Hasil penelitian ini sama dengan penelitian yang dilakukan oleh Hotbin Purba (2014) berjudul "Hubungan Pengetahuan dan Sikap Terhadap Perilaku Remaja Mengenai Abortus Provokatus di SMA Negeri 4 Medan" 110 responden penelitian, siswa/i SMA Negeri IV Medan sebagian besar berumur 16-17 tahun (70\%) diikuti dengan umur 15 tahun (20,9\%), dengan jenis kelamin yang terbanyak dijumpai adalah perempuan $(53,6 \%)$.

Tingkat pengetahuan terbanyak kategori sedang $(51,8 \%)$ dan kategori kurang $(20,9 \%)$. Sumber informasi lebih banyak dari media televisi $(64,5 \%)$. Sikap terbanyak kategori baik $(67,3 \%)$ dan yang terendah kategori sedang dan kurang masing-masing 16,4\%. Perilaku seksual pranikah para siswa/i umumnya menunjukkan risiko rendah (97,3\%). Hasil penelitian mendapatkan bahwa tidak ada hubungan yang bermakna antara tingkat pengetahuan dan sikap siswa/i dengan perilaku seksual pranikah.

Sebagian pengetahuan dari responden dalam kategori cukup dan sebagian besar responden tidak mendukung terhadap aborsi kriminalis hasil dari remaja yang masih belum baik mendapatkan informasi aborsi kriminalis dimana sekolah tidak menyediakan informasi atau tidak memberikan pendidikan khusus mengenai aborsi kriminalis.

Oleh karena itu seharusnya sekolah menyediakan atau memberikan pendidikan tentang kesehatan reproduksi remaja sehingga remaja mendapatkan banyak informasi khususnya tentang bahayanya pergaulan bebas dan tindakan aborsi kriminalis, dimana juga puskesmas bisa menjadi sarana pemberian informasi kesehatan.

\section{Kesimpulan}

Berdasarkan hasil penelitian yang telah dilakukan, maka dapat disimpulkan bahwa tidak ada hubungan antara pengetahuan dengan sikap terhadap aborsi kriminalis. Oleh karena itu disarankan untuk meningkatkan pengetahuan siswi dengan memberikan banyak informasi mengenai aborsi kriminalis, serta bekerja sama dengan puskesmas atau institusi kesehatan untuk pemberian materi tentang aborsi kriminalis kemudian untuk membentuk program genre (PIK-KRR).

\section{Daftar Pustaka}

Ambarawati, Eny Retna, Rismintari, Y. Sriti. 2009. Asuhan Kebidanan Komunitas. Yogyakarta: Nuha Medika 
Arikunto, Suharsimi. 2010. Prosedur Penlitian Suatu Pendekatan Praktik. Jakarta: Rineka Cipta diakses 21 mei 2017 jam 00.21

Handayani, Sri, \& Setyawan, Ferly. 2015. Hubungan Pengetahuan dengan Sikap Seks Pranikah Pada Siswa SMAN1. http://ejournal.unwir.ac.id

Hasmi. 2016. Metode Penelitian Kesehatan. Jayapura: Media

Hermawanto, Hery. 2010. Biostatistika Dasar. Jakarta Timur: CV. Trans Info Media

Hidayat, A, Aziz Alimul. 2014. Metode Penelitian Kebidanan dan Teknik Analisis Data. Jakarta: Selemba Medikahttps://ejournal.unsrat.ac.id/inde x.php/eclinic/article/view/3748 diakses 3 april 2017 jam 18.33

Husain, Mohammad Reza, dkk. 2012. Tingkat Pengetahuan dan Sikap Remaja Puteri Terhadap Bahaya Aborsi Di SMAN 1 Manado

Imron, Moch. 2010. Metodologi Penelitian Bidang Kesehatan. Jakarta: CV Sagung Seto

Kumalasari, Intan \& Adhyantoro, iwan. 2012. Kesehatan Reproduksi Untuk Mahasiswa Kebidanan dan Keperawatan. Jakarta Selatan: Selemba Medika

Kusmiran, Eny. 2012. Kesehatan Reproduksi Remaja dan Wanita. Jakarta: Selemba Medika

Leveno, Kenneth L. 2013. Obstetri Williams. Jakarta: EGC

Machfoedz, Ircham. 2010. Metodologi Penelitian Kuantitatif \& Kualitatif Bidang Kesehatan, Keperawatan, Kebidanan, Kedokteran. Yogyakarta

Marmi. 2014. Kesehatan Reproduksi. Yogyakarta: Pustaka Pelajar

Mubarak, Wahit Iqbal. 2009. Promosi Kesehatan. Jakata: Graha
Nasihah, Mimatun. 2015. Gambaran Pengetahuan Dan Sikap Remaja Putri Terhadap Aborsi di MAN Lamongan. http://journal.unisla.ac.id/pdf/19812 016/e.\%20Bu\%20Mima.pdf diakses 27 mei 2017 jan 00.05

Norma, Nita \& Dwi, Mustika. 2013. Asuhan Kebidanan Patologi. Yogyakarta: Nuha Medika

Notoatmodjo, Soekidjo. 2010. Metodologi Penelitian Kesehatan. Jakarta: PT Rineka Cipta

, 2010. Promosi Kesehatan. Jakarta: Rineka Cipta

Profil Kesehatan Indonesia Tahun 2015 http://www.depkes.go.id/resources/down load/pusdatin/profil-kesehatanindonesia/profil-kesehatan-Indonesia2015.pdf diakses 27 febuari 2017 jam 22.21

Pudiastuti, ratna Dewi. 2010. Kebidanan Komunitas. Yogyakarta: Nuha Medika

Purba, Hotbin. 2014. Hubungan Pengetahuan dan Sikap Terhadap Perilaku Remaja Mengenai Abortus Provokatus di SMA Negeri 4 Medan https://textid.123dok.com/document/8yd49gyphubungan-pengetahuan-dan-sikapterhadap-perilaku-remaja-mengenaiabortus-provokatus-di-sma-negeri-4medan.html diakses 18 juni 2017 jam 20.50

Romauli, Suyanti, \& Vindari, Anna Vida, 2012. Kesehatan Keproduksi Buat Mahasiswi Kebidanan. Yogyakarta: Nuha Medika

SDKI, 2012. Kesehatan Reproduksi Remaja. http://chnrl.org/pelatihandemografi/SDKI-2012.pdf diakses 9 maret 2017 jam 01.56

Sinta, Fitriani, 2011. Promosi Kesehatan. Yogyakarta: Graha Ilmu

Sugiono.2009. Statistika untuk Penelitian. Jakarta: ALFABETA 
Sumantri, Arif, 2013. Metodologi Penelitian Kesehatan. Jakarta: Kencana

Siswanto, dkk. 2014. Metodologi Penelitian Kesehatan dan Kedokteran. Yogyakarta: Bursa Ilmu

Susanti, Yuli, 2012. Perlindungan Hukum Bagi Pelaku Tindakan Pidana Aborsi

(Abortus Provocatus) Korban pemerkosaan.

http://ejournal.unisba.ac.id/index.php/syi ar_hukum/article/download/1470/pdf diakses 15 maret 2017 jam 19.43

Susila, dkk. 2014. Metode Penelitian Epidemiologi. Yogyakarta: Bursa Ilmu

Yulista, Fera, 2014. Pengaruh Pendidikan Kesehatan Tentang Aborsi Terhadap Pengetahuan dan sikap Remaja Putri Tentang Aborsi Di SMK Widya Praja Ungaran.

http://perpusnwu.web.id/karyailmiah/do cuments/3680.pdf, diakses 15 maret 2017 jam 20.28 